\title{
Effects of Dietary Zinc Levels on the Growth Performance, Organ Zinc Content, and Zinc Retention in Broiler Chickens
}

\section{EAuthor(s)

Zhang TY'
Liu JL'
Zhang JL",II
Zhang N",,II
Yang X"I,II
Qu HX"
Xi L"
Han JC"

Institute of Animal Science, Chinese Academy of Agricultural Sciences, Beijing, 100193, China

" Department of Animal Science, College of Life Science, Shangqiu Normal University, Shangqiu, Henan, 476000, China

III College of Animal Science and Veterinary Medicine, Henan Agricultural University, Zhengzhou, Henan, 450002, China

\section{Mail Address}

Corresponding author e-mail address Zhang TY

Institute of Animal Science, Chinese Academy of Agricultural Sciences, Beijing 100193, China

Tel: (010)62816012

Email: zhty999@163.com

\section{aKeywords}

Broiler chickens, growth, requirement, retention, zinc.

\section{ABSTRACT}

The objective of this study was to investigate the optimal zinc (Zn) requirement of broiler chickens based on $\mathrm{Zn}$ retention. On the day of hatch, 350 male Ross 308 broilers were randomly assigned to seven treatments with five replicates of ten birds each. Zinc was supplemented as $\mathrm{ZnSO}_{4} \cdot 7 \mathrm{H}_{2} \mathrm{O}$ at $0,20,40,60,80,100$, or $120 \mathrm{mg} /$ $\mathrm{kg}$ in the starter diet (fed from 1 to $21 \mathrm{~d}$ of age) and at $0,16,32$, $48,64,80$, or $96 \mathrm{mg} / \mathrm{kg}$ in the grower diet (fed from 22 to $42 \mathrm{~d}$ of age). The analyzed $\mathrm{Zn}$ levels were 34.98 and $27.57 \mathrm{mg} / \mathrm{kg}$ in the basal starter and grower diets, respectively. Supplemental Zn levels did not influence body weight gain, feed intake, feed conversion ratio, or liver $\mathrm{Zn}$ content of broilers at 21 and $42 \mathrm{~d}$ of age ( $p>0.05)$. Tibia ash Zn content of 21-d-old broilers increased when $Z n$ supplementation level increased from 0 to $40 \mathrm{mg} / \mathrm{kg} \mathrm{Zn}$ in $(p<0.05)$. The highest breast muscle Zn content in 42-d-old broilers was observed when 100 and $80 \mathrm{mg} \mathrm{Zn/}$ $\mathrm{kg}$ was supplemented in the starter and grower diets, respectively. Fecal Zn content, Zn intake, Zn excretion, and Zn retention of 31- to 33-d-old broilers linearly increased with supplemental $Z n$ levels $(p<0.05)$. Zinc retention values, calculated as the difference between $\mathrm{Zn}$ intake and $\mathrm{Zn}$ excretion, were negative, about zero, and positive when starter/grower diets were supplemented with 0/0 and 20/16, 40/32, and 60/48 and $120 / 96 \mathrm{mg} / \mathrm{kg}$, respectively. These results indicate that supplementing 40 and $32 \mathrm{mg} \mathrm{Zn/kg}$ in starter and grower diets, respectively, promote the growth performance of broiler chickens, while reduce $\mathrm{Zn}$ excretion in the environment.

\section{INTRODUCTION}

Zinc (Zn) is an essential trace element for poultry, and contributes for the maintenance of growth performance (Liu et al., 2011), skeletal development (Ao et al., 2007; Tomaszewska et al., 2017), and immune function (Kidd et al., 1996) of broiler chickens. The Feeding Standards of Chickens in China (Ministry of Agriculture of P. R. China, 2004) indicate that $\mathrm{Zn}$ levels of 100 and $80 \mathrm{mg} / \mathrm{kg}$ are suitable for broiler chickens from 1 to 21 and 22 to $42 \mathrm{~d}$ of age, respectively. However, the NRC (1994) recommends $40 \mathrm{mg} / \mathrm{kg}$ Zn for broilers from 1 to $42 \mathrm{~d}$ of age. Recent research has shown that the optimal levels of supplemental $\mathrm{Zn}$ for the performance of broiler chickens range between 12 and $60 \mathrm{mg} /$ kg for (Ao et al., 2007; Huang et al., 2007; Liu et al., 2011). These data suggest that the $\mathrm{Zn}$ supplementation recommended by the Feeding Standards of Chickens in China (Ministry of Agriculture of P. R. China, 2004) may be higher than the $\mathrm{Zn}$ requirement for broiler chickens and should be revised.

Excessive $\mathrm{Zn}$ supplementation in chicken diets may cause environmental pollution due to $\mathrm{Zn}$ excretion in the feces, as fecal $\mathrm{Zn}$ content linearly increases with $\mathrm{Zn}$ dietary levels in broiler chickens and 
laying hens (Burrell et al, 2004; Kim \& Patterson, 2004, 2005). Moreover, when $\mathrm{Zn}$ load in the soil increases, the $\mathrm{Zn}$ content in plant tissues also increases, hindering plant growth (Schmidt, 1997).

Therefore, this study was conducted to investigate the optimal $\mathrm{Zn}$ requirement of broiler chickens from 1 to $42 \mathrm{~d}$ of age based on $\mathrm{Zn}$ retention.

\section{MATERIALS AND METHODS}

All procedures applied in this study were approved by the Institute of Animal Science of the Chinese Academy of Agricultural Sciences and Shangqiu Normal University.

\section{Birds, Diets, and Management}

On the day of hatch, 350 male Ross 308 broilers were weighed and randomly allotted to seven treatments with five replicates of ten birds each. Broilers were reared in stainless steel cages $(190 \mathrm{~cm} \times 50 \mathrm{~cm} \times 35$ $\mathrm{cm}$ ) in a room with controlled temperature of $33{ }^{\circ} \mathrm{C}$ from $\mathrm{d} 0$ to $3,30^{\circ} \mathrm{C}$ from $\mathrm{d} 4$ to $7,27^{\circ} \mathrm{C}$ from $\mathrm{d} 8$ to 14 , and $24^{\circ} \mathrm{C}$ from d 15 to 42 . A lighting program of $20 \mathrm{~h}$ of light and $4 \mathrm{~h}$ of dark was adopted.

Birds were fed according to a two-phase feeding period: starter (1 to $21 \mathrm{~d}$ of age) and grower ( 22 to 42 $\mathrm{d}$ of age). The basal diets formulated for each phase were based on corn-soybean meal and supplemented with a trace-mineral premix with no Zn (Table 1). The experimental diets (treatments) consisted of the supplementation of $0,20,40,60,80,100$, or 120 $\mathrm{mg}$ of $\mathrm{Zn} / \mathrm{kg}$ diet in the starter phase, and of 0,16 , $32,48,64,80$, and $96 \mathrm{mg} \mathrm{Zn/kg}$ diet in the grower phase. The source of zinc supplemented to the basal diet was $\mathrm{ZnSO}_{4} \cdot 7 \mathrm{H}_{2} \mathrm{O}$, and the feeds were fed as mash. The birds were provided ad libitum access to feed and water during the entire experimental period.

\section{Growth performance parameters}

Feed intake (FI), body weight gain (BWG), and feed conversion ratio $(F C R)$ were calculated for the periods 1 to 21 and 1 to $42 \mathrm{~d}$ of age. All dead birds were weighed and their weight was used to correct the Fl.

\section{Sample Collection}

Fecal samples were collected from trays placed under each cage using the total fecal collection method from 31 to $33 \mathrm{~d}$ of age, and stored at $-20^{\circ} \mathrm{C}$ (Han et al., 2009). Before analysis, fecal samples were dried at $65{ }^{\circ} \mathrm{C}$ for $48 \mathrm{~h}$ and then ground to pass through a 1 -mm mesh screen.
Table 1 - Ingredients and nutrient composition of experimental diets.

\begin{tabular}{lcc}
\hline Item & Day 1-21 & Day 22-42 \\
\hline Ingredients (\%) & 58.02 & 63.18 \\
Corn & 32.07 & 27.52 \\
Soybean meal (43\% CP) & 2.20 & 3.00 \\
Soybean oil & 3.50 & 2.74 \\
Soybean protein isolate (65\% CP) & 1.36 & 1.45 \\
\hline Limestone & 1.94 & 1.36 \\
Dicalcium phosphate & 0.14 & 0.14 \\
L-Lysine-HCl (98\%) & 0.14 & 0.08 \\
DL-Methionine (98\%) & 0.10 & 0.10 \\
Trace-mineral premix' & 0.03 & 0.03 \\
Vitamin premix & 0.20 & 0.10 \\
Choline chloride (50\%) & 0.30 & 0.30 \\
Sodium chloride & 100.00 & 100.00 \\
Total & & \\
Nutrient composition (\%) & 2950.00 & 3054.00 \\
Metabolizable energy (kcal/kg) & 21.07 & 19.08 \\
Crude protein & 1.00 & 0.90 \\
\hline Calcium & 0.69 & 0.58 \\
\hline Total phosphorus & 0.45 & 0.35 \\
Non-phytate phosphorus & 1.10 & 0.90 \\
Lysine & 0.50 & 0.41 \\
\hline Methionine & & \\
\hline
\end{tabular}

${ }^{1}$ The trace-mineral premix (without zinc) provided the following (per kg of diet): $80 \mathrm{mg}$ iron; $8 \mathrm{mg}$ copper; $60 \mathrm{mg}$ manganese; $0.35 \mathrm{mg}$ iodine; and $0.15 \mathrm{mg}$ selenium.

${ }^{2}$ The vitamin premix provided the following (per $\mathrm{kg}$ of diet): $8,000 \mathrm{IU}$ vitamin $\mathrm{A} ; 1,000$ IU vitamin $D_{3} ; 20 \mathrm{IU}$ vitamin $\mathrm{E}_{;} 0.5 \mathrm{mg}$ menadione; $2.0 \mathrm{mg}$ thiamine; $8.0 \mathrm{mg}$ riboflavin; $35 \mathrm{mg}$ niacin; $3.5 \mathrm{mg}$ pyridoxine; $0.01 \mathrm{mg}$ vitamin $\mathrm{B}_{12} ; 10.0 \mathrm{mg}$ pantothenic acid; 0.55 $\mathrm{mg}$ folic acid; and $0.18 \mathrm{mg}$ biotin.

All broilers were weighed per cage on $\mathrm{d} 21$ and 42 . Ten birds per treatment were randomly selected for the collection of the tibia, liver, and breast muscle. Liver and breast muscle samples were frozen at $-20^{\circ} \mathrm{C}$ until further analysis. Tibial bones were boiled for $5 \mathrm{~min}$, and the soft tissues were removed. The bones were then dried for $24 \mathrm{~h}$ at $105^{\circ} \mathrm{C}$ and ashed in a muffle furnace at $600{ }^{\circ} \mathrm{C}$ for $24 \mathrm{~h}$.

\section{Zn Content Analysis}

Zn content in the feed, feces, tibia ash, liver, and breast muscle were determined by inductively coupled plasma atomic emission spectroscopy (IRIS Intrepid II, Thermal Jarrell Ash, Waltham, MA, USA). Follwing the method reported by Huang et al. (2009), approximately $0.5 \mathrm{~g}$ of the samples was weighed in triplicate, digested with $10 \mathrm{~mL} \mathrm{HNO}_{3}$ and $0.4 \mathrm{~mL} \mathrm{HClO}_{4}$ at $200{ }^{\circ} \mathrm{C}$ in a 50-mL calibrated flask until the solution became clear, evaporated to almost dryness, and diluted to 1:20 (vol/ vol) with $2 \% \mathrm{HNO}_{3}$ before analysis.

Zn retention was calculated as follows:

$Z n$ retention $(\mathrm{mg} / \mathrm{bird})=[$ feed intake $(\mathrm{g} / \mathrm{bird}) \times$ feed Zn content $(\mathrm{mg} / \mathrm{g})]-[$ fecal output $(\mathrm{g} / \mathrm{bird}) \times$ fecal $\mathrm{Zn}$ 
content $(\mathrm{mg} / \mathrm{g})]$. The feed and fecal $Z n$ contents were based on their analyzed values. The $\mathrm{Zn}$ content in the basal diet was also included in the Zn intake.

\section{Statistical Analysis}

Replicates were the experimental units used in the statistical analysis. Data were analyzed using the GLM procedure of SAS software (SAS Institute, 2002). Polynomial comparisons were performed to determine the linear and quadratic effects of supplemental $\mathrm{Zn}$ levels on the growth performance, organ $Z n$ contents, and $\mathrm{Zn}$ retention. Means were compared by Tukey test when probability values were significant $(p<0.05)$.

\section{RESULTS AND DISCUSSION}

\section{Zn contents in the basal diets}

The analyzed Zn contents in the basal starter (fed between 1 to 21 days of age) and grower (fed between 22 and 42 days) diets were 34.98 and $27.57 \mathrm{mg} / \mathrm{kg}$, respectively (Table 2). Bartlett and Smith (2003), Ao et al. (2007), Huang et al. (2007), Sunder et al. (2008), Star et al. (2012), and Pacheco et al. (2017) determined that the Zn content of corn-soybean basal diets for broilers ranges from 25 to $35 \mathrm{mg} / \mathrm{kg}$, indicating an average $\mathrm{Zn}$ content of $30 \mathrm{mg} / \mathrm{kg}$. The $\mathrm{Zn}$ content of the basal diet cannot be overlooked when formulating broiler chicken feeds.
Table 2 - Calculated and analyzed Zn levels in experimental diets.

\begin{tabular}{ccccc}
\hline \multicolumn{2}{c}{ Day $1-21$} & & \multicolumn{2}{c}{ Day 22-42 } \\
\cline { 1 - 2 } \cline { 5 - 6 } $\begin{array}{c}\text { Calculated Zn } \\
(\mathrm{mg} / \mathrm{kg})\end{array}$ & $\begin{array}{c}\text { Analyzed Zn } \\
(\mathrm{mg} / \mathrm{kg})\end{array}$ & & $\begin{array}{c}\text { Calculated Zn } \\
(\mathrm{mg} / \mathrm{kg})\end{array}$ & $\begin{array}{c}\text { Analyzed Zn } \\
(\mathrm{mg} / \mathrm{kg})\end{array}$ \\
\hline 0 & 34.98 & & 0 & 27.57 \\
20 & 51.22 & & 16 & 39.16 \\
40 & 84.15 & & 32 & 56.71 \\
60 & 104.22 & & 48 & 67.80 \\
80 & 118.13 & & 64 & 86.99 \\
$100 *$ & 140.52 & & $80 *$ & 121.79 \\
120 & 144.88 & & 96 & 130.89 \\
\hline
\end{tabular}

${ }^{*}$ Zn levels recommended by the Feeding Standards of Chickens in China (Ministry of Agriculture of P. R. China, 2004).

\section{Growth Performance}

The BWG, Fl, and FCR of 21- and 42-d-old broilers were not influenced by supplemental Zn levels $(p>0.05$, Table 3). No linear or quadratic relationships were observed between supplemental Zn levels and growth performance parameters ( $p>0.05$ ).

It is well known that $\mathrm{Zn}$ is an essential element for animals. Zn deficiency results in growth inhibition in animals (MacDonald, 2000). However, broiler performance was not affected by supplemental Zn levels in the present study. Previous studies had also observed that broiler growth was not affected by dietary Zn concentrations (Bartlett and Smith, 2003;

Table 3 - Effects of supplemental Zn levels on the growth performance of broiler chickens.

\begin{tabular}{|c|c|c|c|c|c|c|c|}
\hline \multicolumn{2}{|c|}{ Supplemental Zn (mg/kg) } & \multicolumn{2}{|c|}{ Body weight gain (g) } & \multicolumn{2}{|c|}{ Feed intake (g) } & \multicolumn{2}{|c|}{ Feed conversion ratio } \\
\hline $1-21 d$ & $22-42 d$ & $1-21 d$ & $1-42 d$ & $1-21 \mathrm{~d}$ & $1-42 d$ & $1-21 d$ & $1-42 d$ \\
\hline 0 & 0 & 631 & 2411 & 1073 & 4651 & 1.70 & 1.93 \\
\hline 20 & 16 & 679 & 2415 & 1163 & 4571 & 1.71 & 1.89 \\
\hline 40 & 32 & 705 & 2472 & 1199 & 4703 & 1.70 & 1.90 \\
\hline 60 & 48 & 667 & 2388 & 1126 & 4588 & 1.69 & 1.92 \\
\hline 80 & 64 & 668 & 2417 & 1127 & 4681 & 1.69 & 1.94 \\
\hline 100 & 80 & 619 & 2422 & 1075 & 4632 & 1.74 & 1.91 \\
\hline 120 & 96 & 683 & 2338 & 1176 & 4532 & 1.72 & 1.94 \\
\hline SEM & & 8 & 24 & 13 & 40 & 0.01 & 0.01 \\
\hline \multicolumn{8}{|l|}{$p$ value } \\
\hline Treatment & & 0.051 & 0.910 & 0.067 & 0.935 & 0.579 & 0.972 \\
\hline \multirow{2}{*}{$\mathrm{Zn}$} & Linear & 0.995 & 0.483 & 0.709 & 0.674 & 0.400 & 0.636 \\
\hline & Quadratic & 0.224 & 0.463 & 0.402 & 0.575 & 0.302 & 0.732 \\
\hline
\end{tabular}

Rossi et al., 2007; Sunder et al., 2008; Owens et al., 2009; Yang et al., 2011; Star et al., 2012; Liao et al., 2013; Pacheco et al., 2017; Zakaria et al., 2017). This is attributed to the $\mathrm{Zn}$ content of basal diets (about $30 \mathrm{mg} / \mathrm{kg}$ ), which is adequate to maintain the growth of broiler chickens from 1 to $42 \mathrm{~d}$ of age. Therefore, in the present study, growth performance could not be used as a criterion to evaluate $\mathrm{Zn}$ requirement of broiler chickens. However, other studies showed that broilers fed diets with no supplemental Zn presented lower BWG and FI than those Zn-supplemented diets (Huang et al., 2007; Liu et al., 2011; Sarvari et al., 2015). Moreover, it was observed that high levels of supplemental Zn (500 to $1500 \mathrm{mg} / \mathrm{kg}$ ) impaired the growth performance of broilers (Sandoval et al., 1998; Kim \& Patterson, 2004). 


\section{Zn contents in bone, breast muscle, and liver}

Tibial ash Zn content of 21-d-old broilers linearly increased between 0 and $40 \mathrm{mg} \mathrm{Zn}$ per $\mathrm{kg}$ addition $(p<0.05$, Table 4$)$, but no differences in tibial ash $Z n$ were observed when supplemental $Z n$ levels ranged from 40 to $120 \mathrm{mg} / \mathrm{kg}$. There was no effect of $\mathrm{Zn}$ levels on the tibial ash content of 42 -d-old broilers $(p>0.05)$. Research has shown that supplemental Zn increases blood $\mathrm{Zn}$ concentration in laying hens and broiler chickens (Tsai et al., 2016; Zakaria et al., 2017). A linear relationship was observed between 0 and 20 $\mathrm{mg} / \mathrm{kg}$ supplemental $\mathrm{Zn}$ and bone $\mathrm{Zn}$ content in broiler chickens from 1 to $21 \mathrm{~d}$ of age (Ao et al., 2007; Star et al., 2012). Consistent results were observed between dietary levels of 0 and $40 \mathrm{mg} \mathrm{Zn/kg}$ in starter broilers in the present study. No significant differences were detected between 60-140 mg/kg supplemental Zn and bone Zn content (Huang et al., 2007; Liao et al., 2013). These data suggest that supplemental $\mathrm{Zn}$ increases $\mathrm{Zn}$ absorption in the blood and $\mathrm{Zn}$ deposition in bone, but that bones are not capable of further retaining $\mathrm{Zn}$ when supplemental Zn level is higher than $40 \mathrm{mg} / \mathrm{kg}$.

Supplemental $\mathrm{Zn}$ levels did not influence breast muscle $\mathrm{Zn}$ content of 21 -d-old broilers ( $p>0.05)$. On the other hand, in 42-d-old broilers, the supplemental $\mathrm{Zn}$ levels of 100 and $80 \mathrm{mg} / \mathrm{kg}$ diet promoted the highest breast muscle $Z n$ contents $(p<0.01)$, while the birds fed the highest supplemental Zn level (120 mg/kg) presented similar ( $p>0.05$ ) breast muscle $\mathrm{Zn}$ contents as those fed the diets containing $0,20,40$, and 60 mg supplemental Zn/kg. Sandoval et al. (1998) found that supplemental Zn levels increase muscle Zn content in broilers from 1 to $21 \mathrm{~d}$ of age. By contrast, Kim \& Patterson (2004) found that supplemental Zn levels had no effect on the $\mathrm{Zn}$ level in breast muscles of broilers from 6 to $18 \mathrm{~d}$ of age. The effect of supplemental $\mathrm{Zn}$ level on muscle $\mathrm{Zn}$ content should be further clarified.

Supplemental Zn levels did not affect ( $p>0.05)$ broiler liver Zn content in the present study. In contrast, Sandoval et al. (1998) and Sunder et al. (2008) found that supplemental Zn levels linearly increased Zn content in the liver and kidneys of broilers. These differences may be due to supplemental $\mathrm{Zn}$ levels evaluated among studies. The present experiment evaluated supplemental Zn levels of 0 to $120 \mathrm{mg} / \mathrm{kg}$, whereas Sandoval et al. (1998) and Sunder et al. (2008) used supplemental Zn levels of 0-320 and 0-1500 mg/ $\mathrm{kg}$, respectively.

Table 4 - Effects of supplemental Zn levels on organ Zn contents of broiler chickens

\begin{tabular}{|c|c|c|c|c|c|c|c|}
\hline \multicolumn{2}{|c|}{ Supplemental Zn (mg/kg) } & \multicolumn{2}{|c|}{ Zn in tibial ash $(\mu \mathrm{g} / \mathrm{g})$} & \multicolumn{2}{|c|}{ Zn in fresh breast muscle $(\mu \mathrm{g} / \mathrm{g})$} & \multicolumn{2}{|c|}{$\mathrm{Zn}$ in fresh liver $(\mu \mathrm{g} / \mathrm{g})$} \\
\hline Day 1-21 & Day $22-42$ & Day 21 & Day 42 & Day 21 & Day 42 & Day 21 & Day 42 \\
\hline 0 & 0 & $296.81^{c}$ & 349.58 & 6.79 & $7.82^{\mathrm{bc}}$ & 39.35 & 28.13 \\
\hline 20 & 16 & $371.71^{\mathrm{b}}$ & 355.23 & 6.79 & $7.69^{\mathrm{bc}}$ & 42.96 & 33.85 \\
\hline 40 & 32 & $454.16^{a}$ & 380.77 & 7.16 & $7.64^{\mathrm{bc}}$ & 41.02 & 32.93 \\
\hline 60 & 48 & $465.96^{a}$ & 355.83 & 7.37 & $7.05^{c}$ & 41.93 & 31.15 \\
\hline 80 & 64 & $445.76^{a}$ & 361.63 & 7.06 & $8.71^{\mathrm{ab}}$ & 46.42 & 31.67 \\
\hline 100 & 80 & $450.57^{a}$ & 399.23 & 8.06 & $9.10^{a}$ & 43.95 & 29.41 \\
\hline 120 & 96 & $437.75^{a}$ & 365.57 & 7.42 & $7.55^{c}$ & 44.26 & 29.99 \\
\hline SEM & & 10.85 & 4.96 & 0.14 & 0.14 & 1.30 & 0.90 \\
\hline \multicolumn{8}{|l|}{$p$ value } \\
\hline Treatment & & $<0.001$ & 0.083 & 0.194 & $<0.001$ & 0.866 & 0.676 \\
\hline \multirow{2}{*}{$\mathrm{Zn}$} & Linear & $<0.001$ & 0.076 & 0.027 & 0.024 & 0.259 & 0.726 \\
\hline & Quadratic & $<0.001$ & 0.502 & 0.735 & 0.874 & 0.722 & 0.226 \\
\hline
\end{tabular}

a-cMeans in the same column without a common superscript differ $(p<0.05)$.

\section{Zn retention}

Increasing supplemental $\mathrm{Zn}$ levels linearly increased fecal Zn content, Zn intake, Zn excretion, and Zn retention of 31 - to 33 -d-old broilers $(p<0.05$, Table 5). When supplemental $\mathrm{Zn}$ levels increased from 0 to 120 and $96 \mathrm{mg} / \mathrm{kg}$ in the starter and grower diets, respectively, fecal Zn content, Zn intake, and Zn excretion increased from 137.42 to $388.84 \mu \mathrm{g} / \mathrm{g}$, from 6.09 to $32.99 \mathrm{mg}$, and from 7.49 to $26.69 \mathrm{mg}$, respectively. $\mathrm{Zn}$ intake was lower than the $\mathrm{Zn}$ excretion at 0 to 20 and
$16 \mathrm{mg} / \mathrm{kg}$ supplemental $\mathrm{Zn}$ in the starter and grower diets, respectively. $Z n$ intake was approximately equal to $\mathrm{Zn}$ excretion when in the starter and grower diets were supplemented with 40 and $32 \mathrm{mg} \mathrm{Zn/kg}$, and higher than Zn excretion when supplemental Zn levels were increased from 60 to 120 and 48 to $100 \mathrm{mg} /$ $\mathrm{kg}$ in the starter and grower diets, respectively. Zinc retention was calculated as the difference between $\mathrm{Zn}$ intake and Zn excretion. Broilers presented negative $Z n$ retention values when fed 0 and $20 \mathrm{mg} \mathrm{Zn/kg}$ in the 
Table 5 - Effects of supplemental Zn levels on fecal Zn and Zn retention of 31- to 33-d-old broilers based on the Zn levels analyzed in the feeds and feces.

\begin{tabular}{|c|c|c|c|c|c|}
\hline \multicolumn{2}{|c|}{ Supplemental Zn (mg/kg) } & \multirow{2}{*}{$\begin{array}{l}\text { Fecal Zn } \\
(\mathrm{mg} / \mathrm{kg})\end{array}$} & \multirow{2}{*}{$\begin{array}{c}\text { Zn intake1 } \\
\text { (mg/bird) }\end{array}$} & \multirow{2}{*}{$\begin{array}{c}\text { Zn excretion } \\
\text { (mg/bird) }\end{array}$} & \multirow{2}{*}{$\begin{array}{c}\text { Zn retention } \\
(\mathrm{mg} / \mathrm{bird})\end{array}$} \\
\hline Day 1-21 & Day $22-42$ & & & & \\
\hline 0 & 0 & $137.42^{d}$ & $6.09^{f}$ & $7.49^{c}$ & $-1.40^{b}$ \\
\hline 20 & 16 & $203.43^{c d}$ & $11.16^{\mathrm{ef}}$ & $13.24^{b c}$ & $-2.08^{b}$ \\
\hline 40 & 32 & $206.56^{\mathrm{cd}}$ & $15.20^{\text {de }}$ & $15.49^{b c}$ & -0.29 ab \\
\hline 60 & 48 & $250.12^{b c}$ & $17.90^{\mathrm{cd}}$ & $15.37^{b c}$ & $2.53^{a b}$ \\
\hline 80 & 64 & 294.93 abc & $24.01^{b c}$ & $21.00^{\mathrm{ab}}$ & $3.01^{a b}$ \\
\hline 100 & 80 & $324.47^{a b}$ & $28.99^{a b}$ & $20.84^{\mathrm{ab}}$ & $8.15^{\mathrm{a}}$ \\
\hline 120 & 96 & $388.84^{a}$ & $32.99^{a}$ & $26.69^{a}$ & $6.30^{a b}$ \\
\hline SEM & & 15.30 & 1.61 & 1.26 & 0.90 \\
\hline \multicolumn{6}{|l|}{$p$ value } \\
\hline Treatment & & $<0.001$ & $<0.001$ & $<0.001$ & 0.004 \\
\hline \multirow{2}{*}{$\mathrm{Zn}$} & Linear & $<0.001$ & $<0.001$ & $<0.001$ & $<0.001$ \\
\hline & Quadratic & 0.521 & 0.623 & 0.998 & 0.722 \\
\hline
\end{tabular}

${ }^{a-f}$ Means in the same column without a common superscript differ $(p<0.05)$

'The $\mathrm{Zn}$ content in the basal diet was included in the $\mathrm{Zn}$ intake calculation.

starter diet and 0 and $16 \mathrm{mg} \mathrm{Zn/} \mathrm{kg}$ in the grower diet, approximately zero when fed 40 and $32 \mathrm{mg} \mathrm{Zn}$ in the starter and grower diets, and positive values when fed 60 and $120 \mathrm{mg} \mathrm{Zn/kg} \mathrm{in} \mathrm{starter} \mathrm{diet} \mathrm{and} 48$ and $96 \mathrm{mg}$ $\mathrm{Zn} / \mathrm{kg}$ in the grower diet respectively.

Burrell et al. (2004) and Kim \& Patterson (2004, 2005) verified that fecal $Z n$ content and $Z n$ excretion linearly increased with supplemental Zn levels. Similar results were also detected in the present study. These data suggest that excess $\mathrm{Zn}$ is excreted with the feces in the environment, posing pollution risks. Burrell et al. (2004) found that the $Z n$ intake was lower than the $Z n$ excretion when supplemental $Z n$ ranged from 0 to $40 \mathrm{mg} / \mathrm{kg}$ in broilers from 29 to $31 \mathrm{~d}$ of age. Body $\mathrm{Zn}$ loss resulted in lower bone $\mathrm{Zn}$ content when the $\mathrm{Zn}$ intake was lower than the $\mathrm{Zn}$ excretion in the present study. The Zn intake was approximately equal to the $Z n$ excretion when supplemental Zn was $80 \mathrm{mg} / \mathrm{kg}$ (Burrell et al., 2004). Similar results were observed in this study and the $\mathrm{Zn}$ intake was approximately equal to the $\mathrm{Zn}$ excretion when supplemental $\mathrm{Zn}$ levels were 40/32 $\mathrm{mg} / \mathrm{kg}$. These data suggest that there is a threshold value of $\mathrm{Zn}$ deposition in broiler chickens. When the $\mathrm{Zn}$ retention reaches this threshold, $\mathrm{Zn}$ intake and $\mathrm{Zn}$ excretion are balanced.

The present study also showed that supplemental $\mathrm{Zn}$ did not significantly increase $\mathrm{Zn}$ content in the muscle, bone, or organs of 42-d-old broiler chickens. Therefore, most of the supplemental $\mathrm{Zn}$ was not retained in the chickens' bodies. Excessive $\mathrm{Zn}$ is excreted in the environment by the feces if $Z n$ intake is higher than $\mathrm{Zn}$ requirements. $\mathrm{Zn}$ excretion and its effects on the environment should be considered when supplementing $\mathrm{Zn}$ in broiler chicken diets.

\section{CONCLUSIONS}

The corn-soybean basal diet contained approximately $30 \mathrm{mg} / \mathrm{kg} \mathrm{Zn}$. Supplemental Zn levels of 40 and 32 $\mathrm{mg} / \mathrm{kg}$ in starter ( 1 to 21 days of age) and grower (22 to 42 days of age) diets, respectively, are sufficient to promote adequate growth performance of broiler chickens, also taking into consideration that $\mathrm{Zn}$ excretion in the feces may pose environmental pollution risks.

\section{ACKNOWLEDGMENTS}

This study was supported by the Special Fund for Agro-Scientific Research in the Public Interest of China (201303091), the Innovation Scientists and Technicians Troop Construction Projects of Henan Province (C20130058), and the Foundation of the Education Department of Henan Province (16A230003).

\section{REFERENCES}

Ao T, Pierce JL, Pescatore AJ, Cantor AH, Dawson KA, Ford MJ, et al. Effects of organic zinc and phytase supplementation in a maize-soybean meal diet on the performance and tissue zinc content of broiler chicks. British Poultry Science 2007;48:690-695.

Bartlett JR, Smith MO. Effects of different levels of zinc on the performance and immunocompetence of broilers under heat stress. Poultry Science 2003;82:1580-1588.

Burrell AL, Dozier WA, Davis AJ, Compton MM, Freeman ME, Vendrell PF, et al. Responses of broilers to dietary zinc concentrations and sources in relation to environmental implications. British Poultry Science 2004;45:255-263.

Han JC, Yang XD, Zhang T, Li H, Li WL, Zhang ZY, et al. Effects of $1 \alpha$-hydroxycholecalciferol on growth performance, parameters of tibia and plasma, meat quality, and type Ilb sodium phosphate cotransporter gene expression of one- to twenty-one-day-old broilers. Poultry Science 2009;88:323-329. 
Huang YL, Lu L, Luo XG, Liu B. An optimal dietary zinc level of broiler chicks fed a corn-soybean meal diet. Poultry Science 2007;86:2582-2589.

Huang YL, Lu L, Li SF, Luo XG, Liu B. Relative bioavailabilities of organic zinc sources with different chelation strengths for broilers fed a conventional corn-soybean meal diet. Journal of Animal Science 2009;87:2038-2046.

Kidd MT, Ferket PR, Qureshi MA. Zinc metabolism with special reference to its role in immunity. World's Poultry Science Journal 1996;52:309-323.

Kim WK, Patterson PH. Effects of dietary zinc supplementation on broiler performance and nitrogen loss from manure. Poultry Science 2004;83:34-38.

Kim WK, Patterson PH. Effects of dietary zinc supplementation on hen performance, ammonia volatilization, and nitrogen retention in manure. Journal of Environmental Science and Health Part B 2005;40:675-686.

Liao X, Li A, Lu L, Liu S, Li S, Zhang L, et al. Optimal dietary zinc levels of broiler chicks fed a corn-soybean meal diet from 22 to 42 days of age. Animal Production Science 2013;53:388-394.

Liu ZH, Lu L, Li SF, Zhang LY, Xi L, Zhang KY, et al. Effects of supplemental zinc source and level on growth performance, carcass traits, and meat quality of broilers. Poultry Science 2011;90:1782-1790.

MacDonald RS. The role of zinc in growth and cell proliferation. Journal of Nutrition 2000;130:1500s-1508s.

Ministry of Agriculture of P. R. China. Feeding standards of chickens (NY/T 33-2004). China Agric. Press, Beijing, China. 2004.

NRC. Nutrient requirements of poultry. $9^{\text {th }}$ rev. ed. Washington: National Academic Press; 1994

Owens B, McCann MEE, Preston C. The effect of substitution of inorganic zinc with proteinated or chelated zinc on broiler chick performance. Journal of Applied Poultry Research 2009;18:789-794.

Pacheco BHC, Nakagi VS, Kobashigawa EH, Caniatto ARM, Faria DE, Pacheco BHC, et al. Dietary levels of zinc and manganese on the performance of broilers between 1 to 42 days of age. Brazilian Journal of Poultry Science 2017;19:171-178.

Rossi P, Rutz F, Anciuti MA, Rech JL, Zauk NHF. Influence of graded levels of organic zinc on growth performance and carcass traits of broilers. Journal of Applied Poultry Research 2007;16:219-225.
Sandoval M, Henry PR, Luo XG, Littell RC, Miles RD, Ammerman CB. Performance and tissue zinc and metallothionein accumulation in chicks fed a high dietary level of zinc. Poultry Science 1998;77:13541363.

Sarvari BG, Seyedi AH, Shahryar HA, Sarikhan M, Ghavidel SZ. Effects of dietary zinc oxide and a blend of organic acids on broiler live performance, carcass traits, and serum parameters. Brazilian Journal of Poultry Science 2015;17:39-46.

SAS Institute. SAS user's guide. $9^{\text {th }}$ ed. Cary: SAS Institute; 2002.

Schmidt JP. Understanding phytotoxicity thresholds for trace elements in landapplied sewage sludge. Journal of Environmental Quality 1997;26:4-10.

Star L, Van Der Klis JD, Rapp C, Ward TL. Bioavailability of organic and inorganic zinc sources in male broilers. Poultry Science 2012;91:31153120

Sunder GS, Panda AK, Gopinath NCS, Rao SVR, Raju MVLN, Reddy MR, et al. Effects of higher levels of zinc supplementation on performance, mineral availability, and immune competence in broiler chickens. Journal of Applied Poultry Research 2008;17:79-86.

Tomaszewska E, Muszyński S, Dobrowolski P, Kwiecień M, WiniarskaMieczan A, Świetlicka I, et al. Effect of zinc level and source (zinc oxide vs. zinc glycine) on bone mechanical and geometric parameters, and histomorphology in male Ross 308 broiler chicken. Brazilian Journal of Poultry Science 2017;19:159-170.

Tsai YH, Mao SY, Li MZ, Huang JT, LienTF. Effects of nanosize zinc oxide on zinc retention, eggshell quality, immune response and serum parameters of aged laying hens. Animal Feed Science and Technology 2016;213:99-107.

Yang XJ, Sun XX, Li CY, Wu XH, Yao JH. Effects of copper, iron, zinc, and manganese supplementation in a corn and soybean meal diet on the growth performance, meat quality, and immune responses of broiler chickens. Journal of Applied Poultry Research 2011;20:263-271.

Zakaria HA, Jalal M, AL-Titi HH, Souad A. Effect of sources and levels of dietary zinc on the performance, carcass traits and blood parameters of broilers. Brazilian Journal of Poultry Science 2017;19:519-526. 